\title{
PENGARUH FRAUD DIAMOND THEORY TERHADAP KECURANGAN (FRAUD) PADA KOPERASI KREDIT PINTU AIR
}

\author{
Paulus Libu Lamawitak ${ }^{1 *}$, Emilianus Eo Kutu Goo ${ }^{2}$ \\ ${ }^{1,2}$ Prodi Akuntansi, Universitas Nusa Nipa Indonesia \\ Email : emilyogowic@gmail.com*
}

\begin{abstract}
ABSTRAK
Penelitian ini bertujuan untuk mengetahui pengaruh secara parsial financial target, ineffective monitoring, dan capability terhadap kecurangan (fraud). Data penelitian ini diperoleh dari kuisioner. Penelitian ini termasuk penelitian kuantitatif. Populasi penelitian ini adalah 100 karyawan yang bekerja pada Koperasi Kredit Pintu Air dan teknik penentuan sampel menggunakan rumus slovin. Jumlah responden dalam penelitian ini sebanyak 50 karwayan. Uji keandalan instrument meliputi uji validitas dan uji reliabilitas, uji asumsi klasik meliputi uji normalitas, uji heteroskedastisitas dan uji multikolonieritas. Teknik analisis data menggunakan analisis regresi linear berganda dengan uji hipotesis (uji t). Hasil penelitian menunjukan bahwa (1) financial target berpengaruh signifikan terhadap kecurangan (fraud) dengan nilai signifikan 0,003 < 0,05; (2) ineffective monitoring berpengaruh signifikan terhadap kecurangan (fraud) dengan nilai signifikan $0,002<0,05$; (3) capability berpengaruh signifikan terhadap kecurangan (fraud) dengan nilai signifikansinya $0,000<0,05$.
\end{abstract}

Kata Kunci : koperasi, financial target, ineffective monitoring, capability, fraud

\section{ABSTRACT}

This study aims to determine the effect of partial financial target, ineffective monitoring, and capability for fraud. The data of this study were obtained from questionnaires. This research includes quantitatives research. The population of this study is 100 employees who work at the Sluice Credit Cooperative and the sample determination technique uses the slovin formula. The number of respondents in this study were 50 employees. The instrument reliability test includes the validity and reliability test, the classic assumption test includes the normality test, the heterokedasticity test and the multicollinearity test. Data analysis techniques using multiple linear regression analysis with hypothesis testing ( $t$ test). The results showed that the (1) financial target had a significant effect on fraud with a significant value of 0,003 $<0,05$ (2) ineffective monitoring has a significant effect on fraud with a significant value of 0,002 <0,05; (3) capability has a significant effect on fraud with a significance value of $0,000<0,005$.

Kata Kunci : cooperative, financial target, ineffective monitoring, capability, fraud

\section{PENDAHULUAN}

Pada dasarnya terdapat dua sumber kecurangan, yaitu eksternal dan internal. Kecurangan eksternal (external fraud) adalah kecurangan yang dilakukan oleh pihak luar terhadap entitas. Sedangkan kecurangan internal adalah tindakan tidak legal yang dilakukan oleh karyawan, manager dan eksekutif terhadap perusahaan tempat mereka bekerja (Shintadevi 2015:7). Menurut ACFE (Association of Certified Fraud Examiners) kecurangan (fraud) adalah perbuatan - perbuatan yang melawan hukum yang dilakukan dengan sengaja untuk tujuan tertentu (manipulasi atau memberikan laporan keliru terhadap pihak lain) dilakukan oang-orang dari dalam atau luar organisasi untuk mendapatkan keuntungan pribadi kelompok yang secara langsung atau tidak langsung merugikan pihak lain.

Fraud tidak hanya terjadi di perusahaan saja, bahkan koperasi pun kini ada yang melakukan fraud. Terjadinya fraud tidak terlepas dari lemahnya sistem pengendalian internal. Selain karena lemahnya sistem pengendalian internal, adanya suatu target pemberian kredit juga menjadi salah satu penyebab terjadinya fraud karena dengan adanya target akan 
menimbulkan suatu tekanan (Pradini, 2017 : 2). Koperasi merupakan salah satu UMKM yang ada di setiap daerah. Pengertian Koperasi menurut Peraturan Menteri Koperasi dan Usaha Kecil dan Menengah Republik Indonesia Nomor 13 tentang Perdoman akuntansi usaha simpan pinjam oleh koperasi menyatakan bahwa "koperasi adalah badan hukum koperasi dengan melandaskan kegiatannya berdasarkan prinsip koperasi sekaligus sebagai gerakan ekonomi rakyat yang berdasar atas asas kekeluargaan" sebagaimana dimaksud dalam Undang - Undang Republik Indonesia Nomor 25 Tahun 1992 tentang Perkoperasian".

Koperasi juga merupakan fungsi demokrasi dan sosial, karena para anggota selalu melakukan kerjasama, kegotong - royongan, berdasarkan persamaan hak, kewajiban dan derajat. Ada beberapa jenis koperasi di Indonesia. Salah satunya adalah koperasi simpan pinjam. Menurut Suyanto dan Nuhadi (2003 : 41) koperasi simpan pinjam adalah koperasi yang meningkatkan kesejahteraan anggotanya dengan kegiatan kredit berbunga rendah. Tujuan dari koperasi simpan pinjam adalah untuk meingkatkan kesejahteraan para anggotanya. Modal dari koperasi simpan pinjam (KSP) ini berasal dari modal pinjaman dan modal sendiri.

Salah satu teori yang menjelaskan tentang seseorang dalam melakukan kecurangan adalah teori Fraud Diamond. Teori ini mengatakan bahwa kecurangan disebabkan oleh 4 faktor yaitu tekanan (pressure), peluang (opportunity), rasionalisasi (rationalization) dan kemampuan (capability). Opportunity membuka peluang atau pintu masuk bagi fraud dan pressure dan rationalization yang mendorong seseorang untuk melakukan fraud. Karena adanya kesempatan, tekanan dan rasionalisasi yang ketiga alasan tersebut dapat terjadi jika seseorang memiliki kemampuan.

Penelitian-penelitian terdahulu yang berkaitan dengan judul yang peneliti ambil adalah penelitian Pradini (2017) Pengaruh Financial Target dan Ineffective Monitoring Terhadap Fraud (studi kasus pada koperasi serba usaha dana pertiwi seririt, kecamatan seririt, kabupaten Buleleng, Provinsi Bali) hasil penelitiannya adalah financial target berpengaruh positif dan signifikan terhadap terjadinya fraud, ineffective monitoring berpengaruh positif dan signifikan terhadap fraud, financial target dan ineffective monitoring secara serempak berpengaruh sidnifikan terhadap terjadinya fraud. Penelitian selanjutnya adalah Sihombing (2014) dengan judul penelitian Analisis Fraud Diamond dalam mendeteksi Financial Statement Fraud : studi empiris pada perusahaan manufaktur yang terdaftar di Bursa Efek Indonesia (tahun 2010 2012) hasil penelitiannya adalah financial target, ineffective monitoring dan capability tidak berpengaruh sedangkan financial stability, externall pressure, nature of industry berpengaruh terhadap kecurangan laporan keuangan. Penelitian yang dilakukan oleh Zahara (2017) dengan judul Pengaruh tekanan, kesempatan dan rasionalisasi terhadap tindakan kecurangan (Fraud) (survey pada narapidana Tipikor di Lembaga Permasyarakatan Kelas II A Kota Pekanbaru). Hasil penelitiannya adalah tekanan, kesempatan dan rasionalisasi berpengaruh signifikan terhadap kecurangan (Fraud).

Dari beberapa penelitian terdahulu diatas masih terdapat perbedaan hasil penelitian yang dilakukan masing-masing peneliti dan juga pada penelitian Pradini (2017) hanya menggunakan 2 variabel independen, disini peneliti mengembangkan lagi variabel yang akan diteliti. 


\section{KERANGKA TEORITIS DAN PENGEMBANGAN HIPOTESIS \\ Pengertian Agency Theory}

Teori keagenan (Agency Theory) pertama kali dicetuskan oleh Jensen dan Meckling (1976). Hubungan keagenan merupakan suatu kontrak dimana satu atau lebih orang (principal) memerintah orang lain (agen) untuk melakukan suatu jasa atas nama principal serta memberi wewenang kepada agen membuat keputusan yang terbaik bagi principal. Ketika suatu kontrak disetujui, maka masing-masing pihak memiliki harapan atas keberhasilan terhadap kontrak tersebut. Begitu juga dengan agency theory dimana principal dan agen memiliki kepentingan (interest) masing-masing. Pemegang saham/pemilik sebagai principal diasumsikan hanya mementingkan kepada peningkatan kinerja keuangan perusahaan berupa tingkat pengembalian yang tinggi atas investasi mereka. Akan tetapi agency (agen) juga menginginkan bonus yang banyak atas kinerjanya.

Kinerja agen dinilai berdasarkan kemampuannya dalam mengatur koperasi dengan cara menciptakan pendapatan yang tinggi sehingga SHU yang dibagikan kepada principal juga besar. Semakin besar transaksi yang dilakukan anggota dalam menggunakan layanan koperasi baik jual beli maupun simpan pinjam, maka semakin besar SHU yang akan diterima. Dengan keadaan tersebutlah agency menerima apresiasi dari principal yaitu berupa bonus

Eisenhard (1989:59) dalam Mardiyah (2002:231) menyatakan bahwa teori keagenan dilandasi oleh 3 asumsi yaitu :

1. Asumsi tentang sifat manusia. Asumsi tentang manusia yang memiliki sifat mementingkan diri sendiri (self interest) memiliki keterbatasan rasionalitas dan tidak menyukai resiko (risk aversion)

2. Asumsi tentang keorganisasian. Asumsi tentang adanya konflik antar anggota organisasi, efisiensi sebagai kriteria produktivitas serta adanya Asymmetric Information (AI) antara principal dan agen.

3. Asumsi tentang informasi. Asumsi tentang informasi dipandang sebagai barang komoditi yang dapat diperjualbelikan.

Berdasarkan teori ini, pemilik usaha menginginkan manajemen untuk menampilkan kinerja keuangan sesuai dengan kondisi nyata koperasi sedangkan manajemen berusaha memenuhi permintaan dengan melakukan berbagai cara untuk mendapatkan gaji dan bonus yang tinggi. Dalam teori agensi, dijelaskan bahwa masalah antara principal dan agen timbul karena adanya informasi yang tidak seimbang (Asymmetric information) sehingga dapat memicu terjadinya pelanggaran.

\section{Pengertian Koperasi}

Pengertian Koperasi menurut Peraturan Menteri Koperasi dan Usaha Kecil dan Menengah Republik Indonesia Nomor 13 tentang Perdoman akuntansi usaha simpan pinjam oleh koperasi menyatakan bahwa "koperasi adalah badan hukum koperasi dengan melandaskan kegiatannya berdasarkan prinsip koperasi sekaligus sebagai gerakan ekonomi rakyat yang berdasar atas asas kekeluargaan" sebagaimana dimaksud dalam Undang - Undang Republik Indonesia Nomor 25 Tahun 1992 tentang Perkoperasian. 


\section{Pengertian Fraud (Kecurangan)}

Menurut Association of Certified Fraud Examiners (ACFE, 2016) mendefinisikan kecurangan ( fraud) adalah perbuatan-perbuatan yang melawan hukum yang dilakukan dengan sengaja untuk tujuan tertentu (manipulasi atau memberikan laporan keliru terhadap pihak lain) dilakukan orang-orang dari dalam atau luar organisasi untuk mendapatkan keuntungan pribadi maupun kelompok yang secara langsung atau tidak langsung merugikan pihak lain.

\section{Fraud Diamond}

Fraud diamond merupakan suatu bentuk penyempurnaan dari teori fraud triangle oleh Cressey (1953). Didalam fraud triangle terdapat 3 faktor yang dapat mempengaruhi fraud, yaitu tekanan (pressure), kesempatan (opportunity) dan rasionalisasi (rationalization). Wolfe \& Hermanson (2004) menambahkan satu faktor yang diyakini dapat mempengaruhi adanya fraud, yakni faktor kemampuan (capability), sehingga menjadi empat faktor yang disebut dengan Fraud Diamond.

Fraud diamond adalah suatu faktor yang menjadikan alasan bagi setiap individu untuk melakukan tindak kecurangan karena adanya tekanan, peluang dan rasionalisasi dimana ketiga faktor tersebut dapat terjadi jika individu memiliki kemampuan (capability) dalam melakukan fraud. Capability adalah sifat kemampuan pribadi seseorang yang mempunyai peranan besar yang memungkinkan melakukan suatu tindak kecurangan.

\section{Pengertian Tekanan (Pressure)}

Tekanan yaitu suatu keadaan dimana seseorang merasa ditekan atau tertekan dengan kondisi yang berat saat seseorang menghadapi kesulitan.

\section{Pengertian Peluang (Opportunity)}

Menurut SAS No. 99 menyebutkan bahwa peluang / kesempatan pada kecurangan dapat terjadi pada tiga kategori sebagai berikut :

1) Nature of Industry

2) Ineffective Monitoring

3) Organizational Structure

\section{Pengertian Rasionalisasi (Rationalization)}

Tindakan yang mencari alasan pembenaran oleh orang - orang yang merasa dirinya terjebak dalam suatu keadaan yang buruk. Pelaku akan mencari alasan untuk membenarkan kejahatan untuk dirinya agar tindakan yang sudah dilakukannya dapat diterima oleh masyarakat.

\section{Pengertian Kemampuan (Capability)}

Capability adalah sifat dan kemampuan pribadi seseorang yang mempunyai peranan besar yang memungkinkan melakukan suatu tindak kecurangan. Wolfe \& Hermanson (2004) berpendapat bahwa : banyak fraud yang bernominal besar tidak mungkin terjadi apabila tidak ada orang tertentu dengan capability (kemampuan) khusus yang ada dalam perusahaan. 
Opportunity membuka peluang atau pintu masuk bagi fraud dan pressure dan rationalization yang mendorong seseorang untuk melakukan fraud. Karena adanya kesempatan, tekanan dan rasionalisasi yang ketiga alasan tersebut dapat terjadi jika seseorang memiliki kemampuan. fraud diamond ini yang dapat menjadi alasan seseorang melakukan kecurangan.

\section{Kerangka Berpikir}

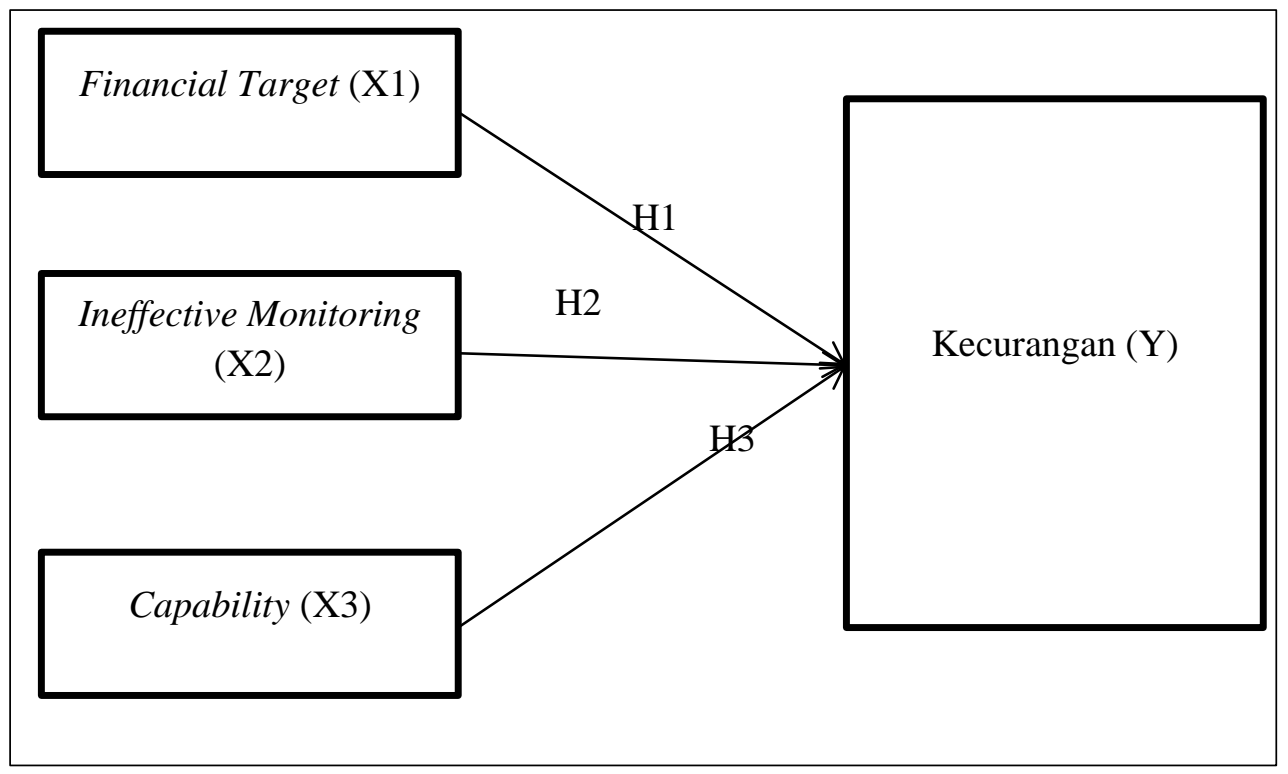

Gambar 1. Kerangka Konseptual

Hipotesis Penelitian

H1 : Financial Target berpengaruh terhadap kecurangan (fraud)

$\mathrm{H} 2$ : Ineffective Monitoring berpengaruh terhadap kecurangan (fraud)

H3 : Capability berpengaruh terhadap kecurangan (fraud)

\section{METODE PENELITIAN}

\section{Rancangan Penelitian}

Penelitian ini menggunakan pendekatan kuantitatif yang bersifat kausatif. Penelitian kuantitatif adalah suatu proses menemukan pengetahuan yang menggunakan data berupa angka sebagai alat menganalisis keterangan mengenai apa yang ingin diketahui (Kasiram 2008 : 149) dalam buku yang berjudulmetodologi penelitian kualitatif dan kuantitatif. Pendekatan kuantitatif bertujuan untuk menguji teori, membangun fakta, memberikan deskripsi statistic, menafsir dan meramalkan hasilnya.

Penelitian kausatif (kausal komparatif) menurut Sugiyono (2010:56) adalah hubungan yang bersifat sebab akibat dengan dua variabel atau lebih. Penelitian kausatif merupakan tipe penelitian dengan karakterisik masalah berupa sebab akibat antara dua variabel atau lebih, sehingga tujuan dari penelitian ini adalah untuk melihat bagaimana pengaruh suatu variabel terhadap variabel lainnya.

Penelitian ini dilakukan pada Koperasi Kredit Pintu Air yang beralamat di Dusun Rotat, Desa Ladogahar, Kecamatan Nita, Kabupaten Sikka, Nusa Tenggara Timur. Populasi 
dan sampel dalam penelitian ini adalah karyawan koperasi kredit Pintu Air yang berjumlah 100 orang. Sampel dalam penelitian ini ditentukan berdasarkan rumus Slovin (dalam Febrianti, 2015). Berdasarkan perhitungan, maka jumlah sampel yang diteliti adalah 50 orang.

\section{Analisis Data}

Data primer yang telah berhasil dikumpulkan dalam penelitian ini, akan dianalisis dengan menggunakan metode analisis kuantitatif, yaitu analisis yang menggunakan angkaangka dan perhitungan statistik untuk menganalisis suatu hipotesis. Sedangkan alat analisis yang digunakan adalah SPSS untuk menguji hubungan antar variabel.

Adapun penelitian ini menguji hipotesis dengan menggunakan model regresi linier berganda untuk memperoleh gambaran mengenai pengaruh fraud diamond theory terhadap kecurangan (fraud)pada Koperasi Kredit Pintu Air. Berikut persamaan regresi linier berganda dalam penelitian ini:

$$
Y=\alpha+\beta_{1} X_{1}+\beta_{2} X_{2}+\beta_{3} X_{3}+\beta_{4} X_{4}+\beta_{5} X_{5}
$$

Keterangan :

$\begin{array}{ll}\mathrm{Y} & : \text { Kecurangan Laporan Keuangan } \\ \alpha & : \text { konstanta } \\ \beta_{1}, \beta_{2}, \beta_{3}, \beta_{4}, \beta_{5} & : \text { koefisien regresi } \\ \mathrm{X}_{1}, & : \text { Financial Target } \\ \mathrm{X}_{2} & \text { : Ineffective Monitoring } \\ \mathrm{X}_{3} & : \text { Capability }\end{array}$

HASIL DAN PEMBAHASAN

Analisis Regresi Linear Berganda

Tabel 1 : Analisis Regresi Linear Berganda

\begin{tabular}{clrrrr}
\hline \multicolumn{6}{c}{ Coefficients $^{a}$} \\
\hline Variabel & $B$ & $\begin{array}{c}\text { Std. } \\
\text { Error }\end{array}$ & T Hitung & Sig. \\
\hline $\mathrm{A}$ & Konstanta & 5.529 & 4.243 & 1.303 & .199 \\
\hline $\mathrm{X}_{1}$ & Fin.Target & -.338 & .106 & -3.190 & .003 \\
\hline $\mathrm{X}_{2}$ & Inef.Mont & .564 & .175 & 3.234 & .002 \\
\hline $\mathrm{X}_{3}$ & Capabilty & .861 & .169 & 5.089 & .000 \\
\hline
\end{tabular}

Bedasarkan hasil perhitungan yang ada pada tabel di atas diperoleh hasil persamaan Regresi Linier Berganda sebagai berikut:

$$
\mathbf{Y}=\mathbf{5 , 5 2 9}-\mathbf{0 , 3 3 8}+\mathbf{0 , 5 6 4}+\mathbf{0 , 8 6 1}
$$

Berdasarkan hasil persamaan di atas dapat diinterpretasikan sebagai berikut:

1. Konstanta sebesar 5,529 menyatakan bahwa jika variable independen dianggap konstan atau memiliki nilai 0 maka besarnya fraud adalah 5,529 satuan.

2. Variable Financial Target memiliki nilai negative atau tidak searah sebesar -0,338, dapat diartikan bahwa jika variable FT meningkat atau naik sebesar 1 satuan, maka kemungkinan terjadinya fraud menurun sebesar $-0,338$ satuan. 
3. Variabel Ineffective Monitoring memiliki nilai positif sebesar 0,564 , artinya jika variable IM meningkat sebesar 1 satuan maka maka terjadinya fraud sebesar meningkat 0,564

4. Variabel Capability memiliki nilai positif sebesar 0,861 artinya jika variable Capability mengalami peningkatan sebesar 1 satuan maka maka terjadinya fraud akan mengalami peningkatan sebesar 0,0861

\section{Uji Simultan (F)}

Tabel 2 : Uji Simultan (F)

\begin{tabular}{|c|c|c|c|c|c|c|}
\hline \multicolumn{7}{|c|}{$A N O V A^{a}$} \\
\hline Model & & Sum of & $D f$ & Mean & $F$ & Sig. \\
\hline \multirow{3}{*}{1} & Rerrecsion & 330646 & 3 & 110215 & 14771 & $000^{b}$ \\
\hline & Residual & 350.687 & 47 & 7461 & & \\
\hline & Total & 681.333 & 50 & & & \\
\hline
\end{tabular}

Dari hasil uji simultan (uji F) diatas dapat diketahui bahwa secara bersama-sama variabel independen memiliki pengaruh yang signifikan terhadap variabel dependen. Hal ini dapat dibuktikan dari nilai probabilitas 0,000 yang memiliki nilai lebih kecil dari 0,05 yang berarti model penelitian ini dapat diterima.

\section{Uji Parsial (t)}

Tabel 3 : Uji Parsial (t)

Coefficients $^{a}$

\begin{tabular}{clrrrr}
\hline Variabel & & $B$ & $\begin{array}{c}\text { Std. } \\
\text { Error }\end{array}$ & T Hitung & Sig. \\
\cline { 1 - 3 } $\mathrm{A}$ & Konstanta & 5.529 & 4.243 & 1.303 & .199 \\
\hline $\mathrm{X}_{1}$ & Fin.Target & -.338 & .106 & -3.190 & .003 \\
\hline $\mathrm{X}_{2}$ & Inef.Mont & .564 & .175 & 3.234 & .002 \\
\hline $\mathrm{X}_{3}$ & Capabilty & .861 & .169 & 5.089 & .000 \\
\hline
\end{tabular}

Tabel diatas menjelaskan masing-masing variabel secara parsial dari hasil output pengolahan data melalui SPSS dan penjelasan untuk tiap-tiap variabel adalah sebagai berikut:

\section{a. Pengujian Hipotesis Financial Target $\left(\mathrm{X}_{1}\right)$}

Pengujian terhadap hipotesis dilakukan melalui pengujian signifikansi koefisien dari variabel Financial Target (X1). Besarnya koefisien regresi yaitu sebesar -3,190 dan nilai signifikansi sebesar 0,003. Pada tingkat sig. $\alpha=5 \%$, maka koefisien regresi tersebut signifikan karena $0,003<0,05$ yang artinya menolak Ho. Berdasarkan hasil pengujian di atas maka dapat disimpulkan bahwa Financial Target (X1) berpengaruh signifikan terhadap fraud (Y) sehingga hipotesis pertama (H1) dalam penelitian ini diterima. 


\section{b. Pengujan Hipotesis Ineffective Monitoring $\left(\mathrm{X}_{2}\right)$}

Pengujian terhadap hipotesis dilakukan melalui pengujian signifikansi koefisien dari variabel Ineffective Monitoring (X1). Besarnya koefisien regresi yaitu sebesar 3,234 dan nilai signifikansi sebesar 0,002 . Pada tingkat sig. $\alpha=5 \%$, maka koefisien regresi tersebut signifikan karena 0,002 < 0,05 yang artinya menolak Ho. Berdasarkan hasil pengujian di atas maka dapat disimpulkan bahwa Ineffective Monitoring (X1) berpengaruh signifikan terhadap fraud (Y) sehingga hipotesis pertama (H1) dalam penelitian ini diterima.

\section{c. Pengujian Hipotesis Capability (X,}

Pengujian terhadap hipotesis dilakukan melalui pengujian signifikansi koefisien dari variabel capability (X1). Besarnya koefisien regresi yaitu sebesar 5,089 dan nilai signifikansi sebesar 0,000 . Pada tingkat sig. $\alpha=5 \%$, maka koefisien regresi tersebut signifikan karena $0,000<0,05$ yang artinya menolak Ho. Berdasarkan hasil pengujian di atas maka dapat disimpulkan bahwa capability (X1) berpengaruh signifikan terhadap fraud (Y) sehingga hipotesis pertama (H1) dalam penelitian ini diterima.

\section{Koefisien Determinasi}

Tabel 5 : Koefisien Determinasi

\begin{tabular}{ccccc}
\hline Model & R & R Square & $\begin{array}{c}\text { Adjusted R } \\
\text { Square }\end{array}$ & Std. Error of the Estimate \\
\hline 1 & $.697^{\mathrm{a}}$ & .485 & .452 & 2.73156 \\
\hline
\end{tabular}

Diketahui nilai Adjusted $R$ Square sebesar 0,453. Nilai Adjusted $R$ Square tersebut menjelaskan bahwa sebesar $45,2 \%$ variabel fraud dijelaskan oleh variabel independen dalam penelitian ini (financial target, ineffective monitoring, dan capability). Sisanya sebesar $54,8 \%$ variabel fraud dijelaskan oleh faktor eksternal lain yang tidak ada dalam penelitian ini.

\section{Pembahasan}

\section{Pengaruh Financial Target Terhadap Kecurangan (Fraud)}

Berdasarkan hasil uji hipotesis yang menunjukan bahwa financial target berpengaruh signifikan terhadap kecurangan (fraud). Pada tabel 4.15 dapat dilihat hasil uji statistik t variabel financial target sebesar 0,003 lebih kecil ari $\alpha=0,05$. Dengan demikian hipotesis H1 diterima sehingga dapat dikatakan bahwa financial target berpengaruh terhadap kecurangan (fraud).

\section{Pengaruh Ineffective Monitoring Terhadap Kecurangan (Fraud)}

Berdasarkan hasil uji hipotesis yang menunjukan bahwa ineffective monitoring berpengaruh signifikan terhadap kecurangan (fraud). Pada tabel 4.15 dapat dilihat hasil uji statistik t variabel ineffective monitoring sebesar 0,002 lebih kecil dari $\alpha=0,05$. Dengan demikian hipotesis $\mathrm{H} 2$ diterima sehingga dapat dikatakan bahwa ineffective monitoring berpengaruh terhadap kecurangan (fraud).

\section{Pengaruh Capability Terhadap Kecurangan (Fraud)}


Berdasarkan hasil uji hipotesis yang menunjukan bahwa capability berpengaruh signifikan terhadap kecurangan (fraud). Pada tabel 4.15 dapat dilihat hasil uji statistic t variabel capability sebesar 0,000 lebih kecil dari $\alpha=0,05$. Dengan demikian hipotesis 3 diterima sehingga dapat dikatakan bahwa capability berpengaruh terhadap kecurangan (fraud).

\section{SIMPULAN, KETERBATASAN DAN SARAN}

Berdasarkan hasil dan pembahasan, maka dapat ditarik kesimpulan bahwa Financial Target berpengaruh signifikan terhadap kecurangan (fraud). Hal ini menunjukan bahwa semakin tinggi tekanan ekonomi yang dirasakan oleh seseorang maka semakin besar pula keinginan seseorang untuk melakukan kecurangan. Hasil berikutnya, Ineffective Monitoring berpengaruh signifikan terhadap kecurangan (fraud). Hal ini menunjukan bahwa belum adanya internal control (pengawasan) yang baik, sehingga memberikan kesempatan bagi pelaku kecurangan untuk melakukan kecurangan, dan terakhir, Capability berpengaruh signifikan terhadap kecurangan (fraud). Hal ini menunjukan bahwa kecenderungan seorang pelaku kecurangan yang merasa yakin bahwa tindakan yang dilakukannya tidak dapat dideteksi sehingga mampu membuat berbagai alasan untuk menutupi kecurangan yang dilakukan.

Berdasarkan hasil kesimpulan maka peneliti mengajukan saran kepada koperasi Kredit Pintu air, diantaranya; (1) Tekanan dalam pekerjaan bisa diberikan tapi koperasi perlu memperhatikan reward \& punishment yang tegas, sehingga karyawan tidak menganggap tekanan sebagai beban tetapi tekanan menjadi motivasi setiap karyawan dalam memberikan kinerja yang lebih baik, (2) Perlu meningkatkan dan memperketat lagi pengawasan terhadap koperasi, dengan cara melakukan pengawasan yang intensif dengan memperketat jadwal pengawasan, melakukan monitoring dan penerapan sanksi terhadap karyawan yang melakukan penyimpangan, (3) Koperasi harus lebih meningkatkan pengawasan terhadap bagian administrasi untuk mencegah kesalahan pencatatan dan pencairan pinjaman kepada anggota, dan (4) Untuk menjaga kelangsungan usaha sebaiknya koperasi tetap menjalankan prosedurnya yaitu dengan melakukan survey berkala dalam upaya mencegah terjadinya kredit macet.

Bagi peneliti selanjutnya dapat menambahkan variabel - variabel penelitian lainnya yang dapat mempengaruhi kecurangan selain 3 variabel diatas (variabel lainnya seperti financial stability, externall pressure, nature of industry).

\section{DAFTAR PUSTAKA}

ACFE. 2016. Reports The Nation on Occupational Fraud and Abuse. Texas: Association of Certified Examiners

Agustia, Dian dan Ade Palupi. 2012. Praktik Creative Acounting Pada Koperasi Di Jawa Timur. Jurnal Ekonomi dan Keuangan. Volume 20, Nomor 4,

AICPA, SAS No.99. 2002. Consideration of Fraud In a Financial Statement Audit. New York: AICPA

Aida Ainul Mardiyah. 2002. Pengaruh Informasi Asimetri dan Disclosure terhadap Cost of Capital”. Jurnal Riset Akuntansi Indonesia. Vol.5 No.2 
Annisya, Mafiana dkk. Pendeteksian Kecurangan Laporan Keuangan menggunakan Fraud Diamond. Jurnal Bisnis dan Ekonomi (JBE), Maret 2016, Hal.72-89. ISSN : 14123126.

Atmadia, Anantawikrama Tungga, dkk. Pengaruh Financial Targets dan Ineffective Monitoring terhadap terjadinya fraud: Studi Kasus pada Koperasi Serba Usaha Dana Pertiwi Seririt, Kecamatan Seririt, Kabuoaten Buleleng, Provinsi Bali. Jurnal Akuntansi Program S1 (Volume 7 No. 1 Tahun 2017).

Bambang, Riyanto. 2001. Dasar - Dasar Pembelanjaan Perusahaan. Yogyakarta: BPFE

Eisenhardt, Kathleen M. 1989. Agency Theory: An Assessment and Review. The Academy of Management Review. Journal. Vol.14,No.1

Farida, Siti Nur. 2017. Analisis Pengaruh Fraud Diamond Personal Atitude dan Effectiveness of Internal Control terhadap Tendensi Kecurangan Karyawan pada Dealer Otomotif di Wilayah Jomang. Skripsi Tidak Diterbitkan. Universitas Diponegoro Semarang

Ghozali, Imam. 2016. Aplikasi Analisis Multivariate Dengan Program (IBM SPSS). Edisi 8. Semarang: Badan Penerbit Universitas Diponegoro

Indriani, Poppy dan M. Titan Terzaghi. 2017. Fraud Diamond dalam Mendeteksi kecurangan Laporan Keuangan. I-Finance Vol.3 No.2

Indriantoro, Nur dan Bambang Supomo. 2002. Metodologi Penelitian Bisnis untuk Akuntansi dan Manajemen. Edisi Pertama, Yogyakarta: BPFE

Karyono. 2013. Forensic Fraud. Yogyakarta : C.V Andi Offset

Kasiram.2008.Metodologi Penelitian Kualittif dan Kuantitatif. Malang : UIN - Maliki Press Malang

Lukman, Hendri dan Viviani Harun. 2018. Faktor yang Mempengaruhi Deteksi Kecurangan dalam Persepsi Auditor Eksternal dan uditor Internal. Jurnal Akuntansi. Volume XXII, No. 02, Mei 2018: 255-265

Mekarsari, Tri Mulin Dewi.2018. Analisis Fraud Triangle dalam mendeteksi Financial Statement Fraud. Skripsi Tidak Diterbitkan. Fakultas Ekonomi dan Bisnis Universitas Muhammadiyah Surakarta.

Munirah, Anisatul dan Ahmad Nurkhin. 2018. Pengaruh faktor-Faktor Fraud Diamond dan Gone Theory Terhadap Kecurangan Akademik. Jurnal Pendidikan Ekonomi. ISSN : 2252-6544, Vol. 7(1)

Murwadji, Tarsisius. 2020. Tanggung Jawab Pemilik Koperasi Pada Saat Terjadi Kredit Macet Ditinjau Dari Teori Kepastian Hukum. Jurnal IUS Kajian Hukum dan Keadilan. Vol III, Nomor 1, April 2020.

Norbarani, Listiana. 2012. Pendekatan Kecurangan Laporan Keuangan dengan Analisis Fraud Triangle yang diadopsi dalam SAS No.99. Skripsi Tidak Diterbitkan. Semarang: Fakultas Ekonomi dan Bisnis Universitas Diponegoro.

Nurbaiti, Zulvi dan Rustam Hanafi. Analisis Pengaruh Fraud Diamond dalam Mendeteksi Tingkat Accounting Irregularities. Jurnal Akuntansi Indonesia, Vol.6 No.2 Juli 2017, Hal. 167-184. 
Peraturan Menteri Koperasi dan Usaha Kecil dan Menengah Republik Indonesia : Nomor 13/Per/M.KUKM/IX/2015 tentang Pedoman Akuntansi Usaha Simpan Pinjam Oleh Koperasi

Putri, Ayu Erika Pradini, Ni Luh Gde Erni Sulindawati dan Anantawikrama Tungga Atmadja. 2017. Pengaruh Financial Target dan Ineffective Monitoring Terhadap Fraud (studi kasus pada koperasi serba usaha dana Pertiwi Seririt, Kecamatan Seririt, Kabupaten Buleleng, Provinsi Bali). E-journal S1 Ak, Volume 7 No. 1 Tahun 2017 Rachbini, Rasiman Widarto. Fraud Diamond dan Deteksi Kecurangan Laporan Keuangan Perusahaan Food and Beverage di Bursa Efek Indinesia. Jurnal Riset Akuntansi dan Perpajakan JRAP Vol.5, No.2, Desember 2018, Hal. 188-200.

Rudewicz, Frank. 2011. The Fraud Diamond: Use of Investigative Due Diligence To Identify The "Capability Element Of Fraud". TMA Connecticut: CTTMA Newsletter, Vol. IV

Shintadevi, Prekanida.F. 2015. Pengaruh Keefktifan Pengendalian Internal, Ketaatan Aturan Akuntansi dan Kesesuaian Kompensasi Terhadap Kecenderungan Kecurangan Akuntansi Dengan Perilaku Tidak Etis Sebagai Variabel Intervening. Jurnal Nominal Volume 4 Nomor 2.

Sihombing, Kennedy Samuel dan Shiddiq Nur Rahardjo. 2014. Analisis Fraud Diamond dalam mendeteksi Financial Statement Fraud : Studi Empiris pada Perusahaan Manufaktur yang terdaftar di Bursa Efek Indonesia (Tahun 2010 - 2012). Diponegoro Jurnal Accounting. Volume 03 Nomor 02

Simanjuntak, Piter. 2008. Pengaruh Time Budget Pressure dan resiko Kesalahan terhadap Penurunan Kualitas Audit. Tesis Tidak Diterbitkan. Semarang : Universitas Diponegoro

Simbolon, Harry ANdrian. 2010. Mengupas Seluk Beluk Fraud dan Cara Mengatasinya.

Diakses melalui https://akuntansibisnis.wordpress.com/200/12/22/mengupas-selukbeluk-fraud-dan-cara-mengatasinya/.html (13 Juni 2020)

Site, M.D.A. 2019. Analisis Prediksi Kebangkrutan Dengan Menggunakan Model Altman

Z-Score Pada Koperasi Kredit Sewilayah Puskopdit Swadaya Utama Tahun 20152017. Skripsi Tidak Diterbitkan. Maumere: Universitas Nusa Nipa

Sugiyono.2005.Metode Penelitian Bisnis, Bandung: Alfabeta.

Sundarwanto, Adenk. 2013. Akuntansi Koperasi. Yogyakarta: Graha Ilmu

Supriyadi. 2014. Statistik Kesehatan. Jakarta: Salemba Medika

Suyanto dan Nurhadi. 2003. IPS Ekonomi. Yogyakarta : Penerbit Erlangga

Tunggal, Amin Widjaja. 2016. Pencegahan dan Pendeteksian Kecurangan. Jakarta: Harvaindo

Undang-undang No. 25 Tahun 1992 Tentang Perkoperasian. 1992. Jakarta : Departeman Keuangan Republik Indonesia.

Wahyuni.2017. Fraud Trinngle sebagai pendeteksi Kecuragan Laporan Keuangan. Jurnal Akuntansi/volume XXI No.01, Januari 2017 : 47 - 61.

Widarjono, Agus. 2015. Statistika Terapan Edisi Pertama. Yogyakarta: UPP STIM YKPN Wolfe, David T and Hermanson, Dana R. 2004. The Fraud Diamond: Considering the Four Elements of Fraud. CPA Journal. Vol 74 Issue 12, pg 38 
Zahara, Ami. 2017. Pengaruh Tekanan, Kesempatan dan Rasionalisasi Terhadap Tindakan Kecurangan. Skripsi Tidak Diterbitkan. Jurusan Akuntansi Universitas Negeri Padang

Zimbelman, Mark F, dkk. 2014. Forensic Accounting. Edisi 4. Jakarta: Salemba Empat. 